\section{The Effect of KWL and SQ3R Strategies on Developing Reading Comprehension Skills Among Eighth Graders in Gaza}

Main Researcher:

Second Researcher:

Third Researcher

1 University Name \& City:

2,3 University Name \& City:
Wafaa Ibrahim Qishta

Prof. Awad Keshta

Prof. Ibrahim Al-Astal

Islamic University of Gaza

Islamic University of Gaza

* Corresponding author:

E-mail address:

Fafiishta@gmail.com

https://doi.org/10.33976/IUGJEPS.29.4/2021/38

The Effect of KWL and SQ3R Strategies on Developing Reading Comprehension Skills Among Eighth Graders in Gaza

\title{
Abstract:
}

The current study aimed at investigating the effect of KWL and SQ3R strategies on Palestinian eighth graders' reading comprehension skills. To achieve the study goals, the researcher adopted the experimental approach on a sample of (119) female students from AlKuwait Secondary School at Rafah governorate for the academic year 2019-2020. The participants were divided into three equivalent groups. The researcher used a pre and post reading comprehension test to achieve the aims of the study.

Results revealed there are statistically significant differences at $(\alpha \leq 0.01)$ in the total average score of the post-test between the first experimental group and the control group in favor of the first experimental group that learns by KWL strategy. Additionally, the study results showed that there are statistically significant differences at $(\alpha \leq 0.01)$ in the total average score of the post-test between the second experimental group and the control group in favor of the second experimental group that learns by SQ3R strategy. Also, the study results revealed that there are statistically significant differences at $(\alpha \leq 0.01)$ in the total average score of the post-test between the first and second experimental groups in favor of the first experimental group. In the light of these results, the researcher introduced some recommendations such as designing some training courses for teachers to encourage them to use these strategies.

Keywords: KWL Strategy - SQ3R Strategy - Reading Comprehension Skills.

\section{أثر استراتيجيتي KML و SQBR على تطوير مهارات الفهم القرائي لدى طالبات الصف الثامن في غزة}

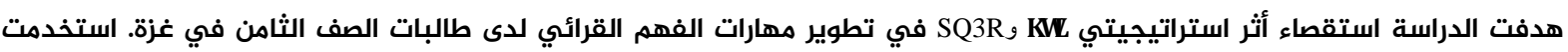

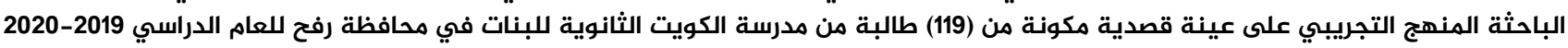

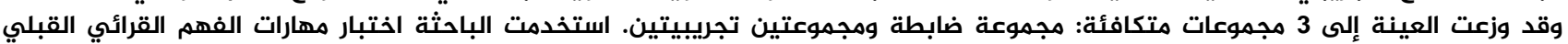
والبعدي لتحقيق أهداف الدراسة.

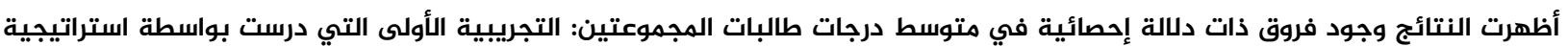

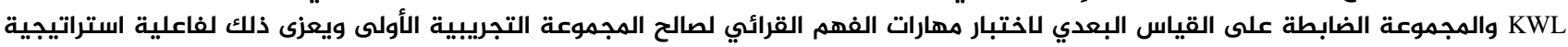

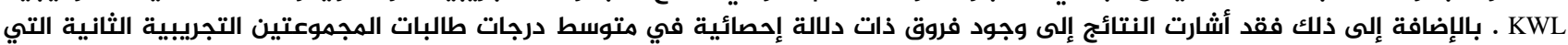

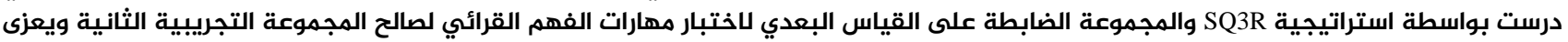

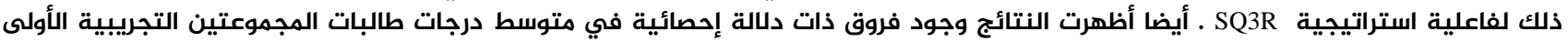

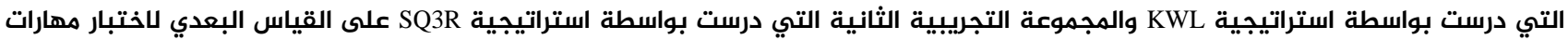

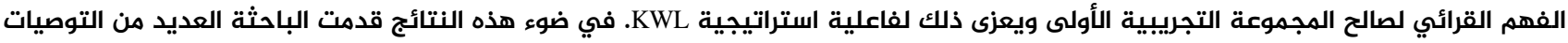
منها إقامة عدة دورات تدريبية لتشجيع المعلمين والمعلمين على استخدام هذه الماته الاستراتيجيات. 


\section{Introduction:}

Learning English language is extremely necessary, because English language has become a significant means of communication everywhere in the world. It is the language of any field such as technology, science, politics, media, commerce, trade, history, and education.

A lot of strategies and ways are used to teach English language as a second language, yet we have difficulties and problems in teaching and learning it. Thus, we need a blend of these methods, ways and strategies to satisfy our aims; that is teaching English language to students to achieve comprehension, accuracy and fluency such as native speakers (Takase, 2009)

Learning and teaching English language is not simple. Actually, the methods and ways teacher present English language as a modern language to their students plays an excellent role in their improvement. Consequently, teachers must do their best to find new methods and ways which enhance and encourage the fast learning of this modern language; they must not stick to normal ways and methods that can impede the required purposes. And to do so, teachers must be updated with recent strategies that students prefer a lot ( Abdal Rahim, 2015).

The researcher noticed that Palestinian pupils' reading comprehension skills are very poor as they lack the capacity to understand their reading texts selections. This is clearly manifested in their exams' results. Consequently, it is a basic topic for teachers to take in consideration new techniques and strategies of teaching reading for the goal of understanding. As El-Kahlout (2010, p.5) stated, most of teachers prefer the using of teaching methods that greatly based on memorizing structures and rules. Pupils are not given the chance to learn language skills or to use language efficiently. Hence, most teachers need new strategies and techniques which interpret language not only as vocabulary, structure or sentences, but also as a practice of culture and thought.

In this aspect, it can say that teachers need to work hard to employ different classroom instructional strategies and make integration of these strategies, so that they help pupils' construction of their own meaning. In this case, pupils are only listeners to what the teachers explain; they do not have an opportunity to articulate what they actually Know about the topics; what they Want to know about the topics, or what they have Learned about the topics. Consequently, teachers of English are advised to be aware of the methods that they could follow when teaching reading to ensure that the reading process is active and purposeful (Rakhmawati, 2015)

For the purpose of developing pupils' reading comprehension skills; Survey-Question-ReadRecite-Review (SQ3R) strategy that stands for Survey- Question- Read- Recall- Review can be used. SQ3R strategy is an interesting reading strategy. It reproduces the reading pattern of competent reader, introduces excellent examples for poor readers to develop, and provides comprehension and purposes for reading. SQ3R enables pupils to improve their reading skills and makes the reading style less hard and more enjoyable (Pribadi,2016).

Therefore, the researcher carried the current study to examine the effect of the Know, Want, and Learn (KWL) and SQ3R strategies on developing reading skills among eighth graders in Gaza. To achieve this goal, the researcher of the current study chose 4 units from English for Palestine Grade 8.

\section{Statement of the Problem}

The researcher is working at UNRWA Prep "B" Girls School as an English language teacher for a decade. During the researcher's expertise in the scope of teaching English language, she observed that pupils face great challenges in English reading skills. These difficulties may related to the ineffective reading comprehension teaching strategies that might influence their achievement. 
So, the researcher feels that there is an urgent need to use more modern techniques to solve the pupils' difficulties they encounter in reading comprehension skills.

Research Questions

The main question is:

What is the Effect of KWL and SQ3R Strategies on Developing Reading Comprehension Skills Among Eighth Graders in Gaza?

The sub questions are:

1. Are there statistically significant differences at $(\alpha \leq 0.05)$ in the total mean scores in the reading comprehension skills posttest between the first experimental group that learns by KWL strategy and control group that learns by the traditional method?

2. Are there statistically significant differences at $(\alpha \leq 0.05)$ in the total mean scores in the reading comprehension skills posttest between the second experimental group that learns by SQ3R strategy and control group that learns by the traditional method?

3. Are there statistically significant differences at $(\alpha \leq 0.05)$ in the total mean scores in the reading comprehension skills posttest between the first experimental group that learns by KWL strategy and second experimental group that learns by SQ3R strategy?

\section{Research Hypothesis}

1. There are no statistically significant differences at $(\alpha \leq 0.05)$ in the total mean scores in the reading comprehension skills posttest between the first experimental group that learns by KWL strategy and control group that learns by the traditional method?

2. There are no statistically significant differences at $(\alpha \leq 0.05)$ in the total mean scores in the reading comprehension skills posttest between the second experimental group that learns by SQ3R strategy and control group that learns by the traditional method.

3. There are no statistically significant differences at $(\alpha \leq 0.05)$ in the total mean scores in the reading comprehension skills posttest between the first experimental group that learns by KWL strategy and second experimental group that learns by SQ3R strategy.

\section{Purpose of the Study}

1. Discussing the nature of SQ3R and KWL strategies.

2. Improving eighth graders English language reading comprehension skills through using SQ3R and KWL strategies.

\section{Significance of the Study}

The process of teaching reading skill in a traditional way was become boring as a result of the coming of effective and modern strategies that activates pupils to be careful and interested readers. Palestinian teachers must be aware of these effective and modern methods and their effect on developing pupils' skills and their effect on increasing their reading competencies. The current study was conducted to examine the effect of KWL and SQ3R strategies on developing reading comprehension skills with the trust that most of Palestinian teachers and pupils will become more conscious of the effect of KWL and SQ3R strategies on improving reading comprehension skills among eighth graders. The significance of the current study is summarized in the following point:

1. Teachers and lecturers of English could have the benefit of the work and wish to use the SQ3R and KWL strategies in teaching reading skills.

2. The current study can be helpful for supervisors to carry out some training courses for teachers and lecturers of English language to increase their consciousness of the significance of using the SQ3R and KWL strategies in teaching reading skills. 
3. This study may increase Eighth graders' anticipation to be aware of the significance of getting smart reading capacity to achieve higher academic benefits.

4. Additionally, this study provides an experimental model to indicate the effectiveness of KWL and SQ3R strategies to improve eighth graders English reading skills.

5. This study can contribute to develop and rise the process of teaching English generally and the reading skills particularly.

\section{The study Limitations}

- The study was applied through the first semester of the scholastic year 2019/2020.

- The study was conducted on Grade eight female students studying at Kuwait Secondary School at Rafah governorate.

- The current study was restricted to the impact of KWL and SQ3R strategies on improving eighth graders English reading comprehension skills.

- The study was conducted on four units (two,three, four and, five).

- The study was conducted on the following reading skills: scanning- skimming- synonym and antonym - making inference- taking notes.

- The tool of the current study was constructed by the researcher.

\section{Operational Definition of Terms}

\section{KWL strategy}

The researcher defines KWL strategy as a method that is used in instructing reading; it is a strategy in which teachers generate a debate about specific topics and employ chart tables or worksheets to write learners sentences concerning what they already know "K"; want to learn "W", and after reading, what they have been learning "L". Additionally, this strategy can be used to help teacher in activating learners' previous knowledge of topics. Also, KWL strategy introduces a chance for learners to expand their ideas and design new ones.

\section{SQ3R Strategy}

SQ3R is standing for survey- question- read- recite - review. It is a reading comprehension method improved for reading texts and activities for different students. It improves active attitudes toward studying and activate the cognitive processes of effective pupils. Additionally, SQ3R strategy was a comprehension method that assists learners to go beyond topic they are studying while they are reading. SQ3R assists learners to be involved in the reading topic from the first time via teaching them how to read and imagine like efficient readers.

\section{Reading Comprehension}

Reading comprehension is one of the necessary tasks and activities that done in every language classroom. It is the capacity to read the texts then processing them and comprehend their meaning.

\section{KWL Strategy}

\section{Literature Review}

KWL strategy involves 3 essential notions: Know, Want and Learn. This strategy was first improved by Ogle in year 1987 on the basis of ideas that language learner gains information via building meanings. As referred by Ogle, several known researchers (Steffenson, Joag-Dev and Anderson, 1984; Anderson, 1978, Guthrie and Taboada, 2005) come to an agreement that smart pupils connect their previous information to new ones; realize it; and then inspire their own meanings. Moreover, she assures that the KWL strategy supply a good framework for learners that could be utilized across content areas in order to assist them build meaning.

Additionally, the strategy was prepared to be used via teachers and groups of learners working with each other. It later might aimed to lead learners for autonomous studies. In the stage of implementing this strategy, teachers initially conduct oral discussions of each component of the 
KWL and permit the procedures go on to learners' individual writing of their own questions and ideas on particular worksheets ( Asri, 2014).

Since its origin, the KWL strategy is utilized as an instructional reading strategy in order to assist new lecturers engage pupils from the start of a reading text via stimulating previous information. The KWL strategy additionally assists lecturers to keep learners enjoyed as they think about what they want to know; and what they have been learning (Sasson, 2008). Accessing prior information and activating students' attention before starting a reading task could develop students' capacity in making association, enhance comprehension; and increase attentions (McKenna, 2003, p.2). Students' skills are increased in stating goals for reading, searching knowledge from text, arranging that knowledge into graphics outline and writing summary depending on those graphics outline (Badr El Deen, 2009).

\section{Benefits of KWL Strategy for Readers}

KWL Strategy is one of the learning and teaching strategies that utilized mainly for organizing text ; it assists readers to:

- Arouse previous information of topics of different texts.

- Put goals for reading.

- Observe readers' understanding.

- Evaluate readers' understanding of texts; and extend different ideas beyond texts.

- Assist learners to be effective readers in expository texts.

- Rise the rate of retentions of reading materials and develop learners' capacity to make relations among several groups of knowledge and increase their motivation for reading nonfiction ( Ogle,1986, p. 564 - 570).

- KWL strategy introduces a chance for learners to extend ideas beyond texts.

- KWL strategy assists students choose what they like to learn concerning the subject that introduces the self-enthusiasm to read and create different questions.

- KWL strategy assist with self-observing of understanding because it permits the learners to clarify what they comprehend (Conner, .2006, p. 1).

- KWL strategy provides a chance for learners to extend on their ideas and constitute new ones (Szabo, , 2006, p. 58).

\section{Advantages of Using KWL Strategy}

Ibrahimi (2005, p. 126), Al-Taie (2010, P. 252-253), Salah (2008, p. 40-41) and Abdal Rahim

(2015,p. 28) listed the benefits of using KWL strategy as the following:

1. KWL encourages such ideas that let learners the center of teaching-learning process instead of teachers.

2. KWL gives teachers the chance to start school years with obvious goals whether that goals are being achieved or not.

3. KWL emphasizes on pupils to be self-dependence and autonomous learners.

4. KWL qualifies students to get an important progress in the learning process.

5. KWL activates and arouses learners' enthusiasm to study and qualifies students to study topics regardless the degree of its difficulty.

6. KWL could be utilized in all levels of school and learning subjects.

7. KWL stimulates previous information that existed in the long-term memories.

8. KWL assists learners to remember and recall the previous information.

9. KWL attracts students and assists them to specify goals of learning for given texts.

10. KWL arranges the thinking process among learners via asking questions and responding to these questions. 


\section{SQ3R Strategy}

Robinson improved this method in 1940s (Robinson, 1941). He was entitled as "The grandfather of study strategies" (Lipson \& Wixson, 2003). SQ3R is standing for 5 steps which learners are following when using this strategy. These five steps are survey- question- read- recite- review.

1) Survey: In this step, students skim topics to get general idea of the text.

2) Question: In this step, students ask questions concerning what they need to learn from the topic.

3) Read: In this step, students read topics in the same time they are searching for answers to the previously questions.

4) Recite: In this step, students reprocess prominent ideas of texts via written and oral language.

5) Review: In this step, students assess the significance of what they have already read and mix it into long-term relations. These sets of steps work as a general guide for helping students to achieve better reading comprehension; consequently, teachers should adopt this strategy with its steps in their teaching process.

SQ3R strategy was a reading comprehension method improved for reading texts and activities for different students. It improves active attitudes toward studying and activate the cognitive processes of effective pupils. Additionally, SQ3R strategy was a comprehension method that assists learners to go beyond topic they are studying while they are reading. SQ3R assists learners to be involved in the reading topic from the first time via teaching them how to read and imagine like efficient readers (Asiri \& Momani, 2017).

SQ3R strategy is a dynamic reading strategy which organized to assist students to get clear comprehension about reading topics. Students require to have papers and pens on their hands for using this strategy (Fleming, 2019).

\section{The Advantages of SQ3R Strategy}

Wood (2000:169) stated the following advantages for SQ3R Strategy:

- It motivates information and imagining concerning texts even before students begin the process of reading.

- It permits students to revise knowledge as they study it.

- It presents a study guide that could be used to revise for test.

- The learners do their best to find answers for questions depending on the context of reading passages.

- Learners could help each other in groups to exchange ideas that existing in the reading passage.

- The sequence of SQ3R is powerful because the steps of survey and question make students get a sense with the text they will read. Besides, it provides students a means that involve them to monitor their comprehension.

- The step of survey guides students to be familiar with the text. It is stated that familiar material is always easier and more enjoyable to comprehend.

- Question as the second step of SQ3R helps students to concentrate and think about the material.

- Recitation as the fourth step of SQ3R helps students to transfer new material in the longterm memory.

\section{Reading}

Reading is a necessary and basic skill that fulfills many purposes besides fun and success for students. Reading is an important element in our life, and it is the key to the doors of information and science. It is called via Islam verse one that directed to the Prophet Muhammad, namely (Read). Islam emphasized on the significance of education and reading, and the Holy Quran is regarded as 
the heavenly resource which assures its significance. The first verses of the Holy Quran which are directed to the Holy Prophet emphasized the actual necessity of reading (Abdal Rahim, 2015).

\section{Definition of Reading}

Miller (2012, p. 8) defines reading as the capacity to comprehend and to obtain meaning from any kind of written subjects. It is the important element of the whole learning process".

Reading also can be defined as a systematic, cognitive and visual process that aims at processing information, extracting meaning from written text and connecting it to existing experience (Millord, 2001). Another definition for reading focuses on the interface of multiple structures in the brain and its behavioral product. These interactions happen through executive function processing, relational processing, distributed nets which appear mainly metabolically active to visual and auditory reactions (Willis, 2009).

Moreover, reading was a compound procedures that are not a straightforward process of moving terms and concepts off the passage. It is a kind of problem solving that readers try hard to understand reading passages not just from the terms and concepts on the passages, but also from the memoires and information that raised from these sentences and words (College of the Canyons, 2012).

\section{Importance of Reading Comprehension}

Reading comprehension is one of the necessary tasks and activities that done in every language classroom for a number of reasons:

1. It functions as a mean of increasing students' knowledge of the language being learnt (Behjat, 2011).

2. It gives the enormous contribution to learners to perform their communication skills better (Afida, 2008).

3. It is one of the most frequently used language skills in daily life, as witnessed by the use of the internet (Medina, 2012).

4. It helps students to build meaning by focusing on the relevant features of the texts and to relate those features to their previous experiences.

5. It helps readers to find meaning in what is read (Mohamad, 1999).

\section{Types of Reading}

\section{Extensive Reading}

There are several meanings for extensive reading. Hedge (2003) defined it as scanning and skimming exercises while Hafiz and Tudor (1989 as cited in Alyousef 2005) stated that it is offering students to big amounts of interesting and meaningful materials. Also, tasks in extensive reading have an important impact on students' information of L2. Many studies have revealed good interest in extensive reading recently.

According to Carrell and Eisterhold (1983 as cited in Alyousef 2005), extensive reading activities may be useful in helping students to be more self-directed people who are looking for meanings which depend on learner-chosen topics which students are enjoyed in what they read. The procedure of selecting reading topics is done according to context, length and rate of difficulty. Hedge (2003) indicated the advantages of extensive reading as the following: Learners may improve their language achievement, progress in reading skills, be more autonomous in their studying, acquire cultural information and increase confidence to carry on their studying.

\section{Intensive Reading}

In intensive kind of reading, students examine a page to discover concepts and to be customary with the different methods of reading. Via this kind of reading, students may obtain essential training in acting these different methods depending on a set of subjects. These methods 
can be learner-related or text-related. Learner-related includes strategies such as linguistic, metacognitive and schematic strategies and the second involves recognition of text organization (Hedge, 2003).

Yang, Dai and Gao (2012) indicated that intensive reading is important to improve reading understanding. According to Waring (1997), this kind of reading is necessary for studying concepts and comprehending how texts are shaped. Stahl (2003) discovered that there was a connection between intensive reading tasks and language proficiency. As Paran (2003) stated, instructors require intensive reading to rise the 3 stages of reading that: pre, during, and while-reading for good language readiness, activation strategies and retention. Simmons, Pollar, Durodo, Gonzalez, Kwok, Taylor, Davis and Simmons (2011) stated that intensive reading was considered as an important tool for developing reading understanding.

\section{Reasons for Weaknesses in Reading}

Undoubtedly learners here in Palestine like many learners in other countries, are facing difficulties and have weak performance in studying English in general and reading in particular. That weakness might be because of the follows:

1. Shortage of knowledge among students concerning the reading passage and its concepts, terms and structure.

2. A lot of instructors use the same strategies for instructing reading.

3. Several of the reading kinds are neglected in the classrooms like aloud reading.

4. Not adequate time is available for pupils to train on silent reading.

5. Shortage of self-confidence among the learners, in which some of them are fearing of doing errors in front of other students.

6. No concerning about the supplementary reading (Abdal Rahim,2015 ).

Actually, the former reasons might rise difficulties and challenges in studying reading and in achieving understanding, but the researcher thinks that one of the major causes for reading understanding difficulties is that a lot of instructors do not employ the suitable and appropriate strategies of the textbooks properly. To overcome the previous difficulties problems, teachers can use reading strategies such as KWL and SQ3R strategies.

\section{English for Palestine Grade 8 (English for Palestine Teacher's Book 8,2013)}

English for Palestine Grade 8 contains the following elements:

- Two students Books (8A for the first semester and 8B for the second semester)

- One Teacher's Book.

- Four Audio CDs.

The Aims of Grade 8 (English for Palestine Teacher's Book 8,2013)

The objectives of Grade 8 are:

- To present high-frequency English terms.

- To present easy and gradually more difficult grammatical rules.

- To give chances for learners to involve in meaningful tasks of English.

- To train and expand student's capacities in the main skills of speaking, listening, writing and reading.

\section{Studies Related to KWL Strategy}

\section{Previous Studies}

\section{Al-salhi (2020)}

This research endeavored to examine the impact of KWL strategy in 4th grade pupils' performance in reading and their attitudes towards employing this strategy. It compares the outcomes of various methods of teaching the texts of reading, and learners attitudes towards their 
employing. The research is implemented via employing the quasi-experimental design case study. The sample of the research is 62 learners, categorized into 2 groups: one is an experimental and the other is a control. Each of them consists of 32 pupils. A questionnaire and achievement exam were built to check the study's reliability and validity. The results showed that there were an importance variation between the control and experimental groups, in favor of the experimental one, and students' attitudes are also affirmative towards the employing the KWL strategy. The research recommended further studies in the employing of KWL strategy in other levels.

\section{Rahman (2019)}

The aims of this study were to discover if the employing of KWL strategy with Prezi fosters the students' interest and the reading comprehension. The study used the quasi experimental design. The population of this study was the $1^{\text {st }}$ grade learners of SMA in year 2017/2018. The study used cluster random sampling method. The participant of this study contained seventy two learners who belong to 2 groups; thirty six learners in experimental group and thirty six learners in control group. The study tools were employed to gather data in the study mainly questionnaire and reading comprehension exam. The outcomes of the learners' reading marks in the study revealed that the experimental group developed significantly from 68.59 up to 87.41. while, the results of the control group developed from 67.42 up to 71.81. Consequently the alternative supposition (H1) was agreeable. Additionally, relied on the learners' answers' on questionnaire revealed that the mean scores of interest was 81.72, and it was classified as interested.

\section{Usman, Fata and Pratiwi (2018)}

This research aimed to investigate the effect of teaching reading by employing KWL strategy. This research employed. The quantitative way via having 1 pre-test and posttest study design, implemented with participants of 28 learners. The exam was examined via using t-test. The research showed that there was a development from the pre-test to the posttest and that the instructor had conducted the KWL strategy accordingly, so that the learners developed their reading understanding skills. Furthermore, KWL strategy is one of the important methods improved to know the extension of students' capacity and the method they commit it by themselves. So, the strategy itself has an impact to stimulate the learners to become independent students. However, it was recommended that instructors adapted some procedures in the KWL steps to stimulate the learners in studying reading.

\section{Rusmati (2017)}

The objective of this study is to improve learners' reading skills via implementing the KWL method to the 11th grade students. The author implemented this study to solve the difficulties faced in the classrooms. Since it is to develop reading skills, the appropriate method that was implemented in the study is a classroom action research. The sample of the study was learners in 11th grade in Academic 2016/2017 that contains thirty one learners. Data were gathered via employing observation and achievement exam. There were 3 cycles of classes action research procedures. In the first one, the learners are still do not know how to apply KWL method, and several learners cannot achieve even low marks the test. In the second cycle, the pupils realized how to apply the KWL strategy, and the marks were better than first cycle. And the last cycle, the learners' marks were better. The outcomes of the study refer the learners' reading comprehension mean scores were $76.15,90.52$, and 98,93. According to the findings, KWL method can develop learners' reading comprehension.

\section{Dieu (2016)}

The research focused on the significance of the previous knowledge (Schema) theory in reading understanding. To conform the advantage of previous information, KWL method was 
employed as treatment in the experiment. The hypothesis was that the KWL strategy can assist weak learners to develop their reading skills. 70 pupils were taken as sample in this study. The sample is classified into 2 groups. The author employed pre and posttest instruments about reading comprehension skills. The ultimate aim was trying to replace learners' attitudes from negative to positive towards reading topics after the KWL strategy was employed and to develop Vietnamese learners' reading skill as well as getting the main ideas in the reading topics to have great connection in English language. Consequently, the study has affirmed the positive impact of the experiment. It additionally recommended a method to manage the reading class, to produce an enjoyment, fun and interesting mood to develop students' reading comprehension skills.

\section{Studies Related to SQ3R Strategy \\ Anjuni and Cahyadi (2019)}

This study has aim to figure out the impact of employing SQ3R method in developing learners' reading understanding. The population of the study is learners of $11^{\text {th }}$ grade of IPA and IPS classes. The number of population is sixty learners. The participants of the study are just 1 class which is IPS class that contains 30 learners. The quantitative research technique was employed in the study, and mainly the 1 group pre-test post-test design as research design. The tool of the study was pretest and posttest, and the researchers additionally utilize t-test formulation for gathering information. The alternative hypothesis in this research is admitted. According to the data analysis that was gathered, it could be said that the exam was reliable. Also, the study revealed that instructing learners reading comprehension by employing SQ3R strategy is very effective and suitable in developing pupils' reading comprehension.

\section{Bakhtiar (2018)}

The author of this research employed an action research. For gathering data, the researcher used observation and test. The data sources are the eleventh grade that consists of 38 learners, and an English teacher as an observer. Cycle 1 consists of planning, observation, action and reflection. Cycle 2 added by the revision of cycle 1 . Relied on the outcomes of the research, in cycle 1 the percentage of learners who achieved Minimum Accomplishment Criteria (MAC) 75 was 64\% In other words, 25 learners had achieved Minimum Accomplishment Criteria (MAC), while 15 learners had not reached MAC In .cycle 2, all of learners have reached Minimum Accomplishment Criteria (MAC). The outcomes showed, in cycle 2 all of the learners could comprehend the texts and determine the main ideas and reached .Minimum Accomplishment Criteria (MAC) in reading it is 75. Consequently, there is a significant developing in using the SQ3R strategy to increase the learners' reading comprehension at the eleventh grade.

\section{Pribadi (2015)}

This study aims to investigate how SQ3R reading strategy assists $10^{\text {th }}$ graders of SMA Negeri 1 East Java to solve their problems and challenges in reading descriptive texts. The study was a Classroom Action Research that includes of 2 cycles. In each one, the researcher lead the class to implement the SQ3R strategy that includes several steps: surveying questioning, reading, reciting, and reviewing. It was found that the SQ3R reading strategy could assist in improving the learners' ability in reading descriptive text via providing a structured approaches for reading tasks and activities.

\section{Fikri ( 2015 )}

The research was categorized as a Classroom Action Research. The research aimed to investigate the impact of SQ3R method with its five steps on reading comprehension of the learners XI class of SMA ITMA Jombang to help the learners' in finding solutions to their weakness on reading skills. The researcher reached to the next data: 1 . Teachers still used instructor-oriented 
methods, 2. Learners have inadequate comprehension in reading English texts; 3. Learners cannot understand the hard texts, 4. Learners were passive and not stimulated to read an English texts. Consequently, the norm of success was sequenced to those difficulties. The findings in the study revealed that via applying the SQ3R as the reading strategy in 2 cycles, the learners' reading skill was developed and then their involvement in classes were highly improved.

Baier (2011)

This research is implemented for the goal of identifying if associating the SQ3R strategy into $5^{\text {th }}$ grade learners reading methods can develop their overall. The research additionally examined learners' previous reading methods and their beliefs on whether they will go on to conduct SQ3R strategy into their reading habits. The findings of the research revealed that SQ3R strategy significantly developed $5^{\text {th }}$ grade pupils' comprehension score of expository text. The research furthermore revealed that $47.8 \%$ of the pupils participated in the research have a previous reading method. The most popular previous reading method is note taking. It was found that $69.8 \%$ of the learners participated in the research will employ the reading method SQ3R in the future. It is suggested that instructors and administrators realize the significance of reading methods and introduces for learners and parents appropriate techniques and methods which may be employed to develop understanding.

\section{General Commentary about the Previous Studies}

1. The findings of several prior researches revealed the presence of common failure in reading comprehension skills in most stages that provide the requirement to conduct the current study.

2. The majority of the prior researches showed that there is a great relation between previous information and reading comprehension skills. The more previous information pupils have concerning the reading texts, the more they will be able to understand topics.

3 . The prior studies focused on the significance of pre-reading exercises and tasks as instructional methods for the improvement of the reading comprehension skills.

4. The prior researches showed that stimulating previous information and improving reading comprehension skills can be developed via implementing methods relied on KWL and SQ3R strategies.

\section{Research Design}

The Methodology

The researcher adopted the experimental approach. There were three groups: The first one studied by KWL strategy, the second one studied by SQ3R strategy and the third one studied by the ordinary method.

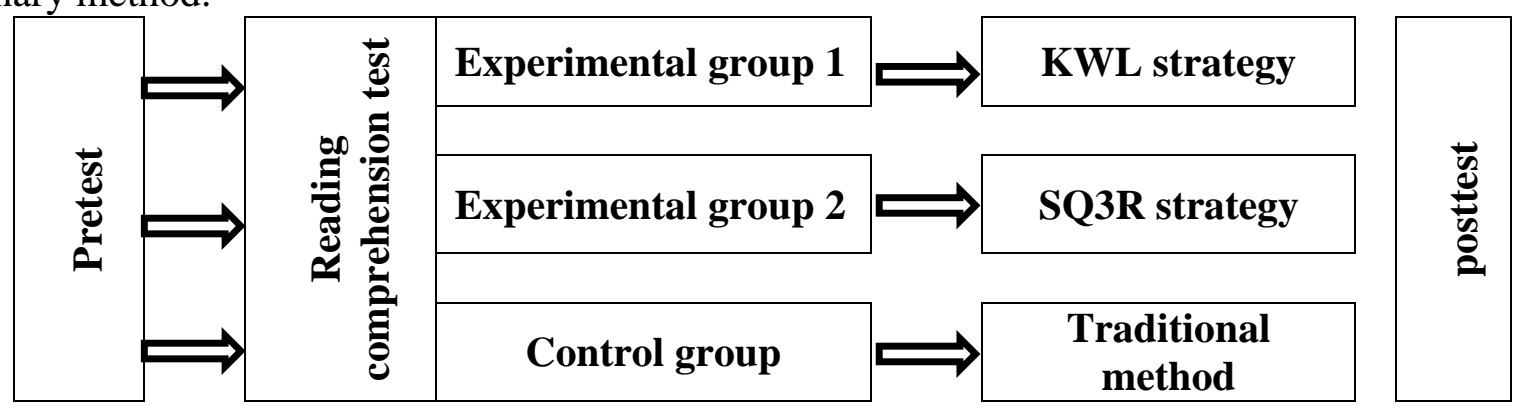

Figure (1): Design of the Research 


\section{Population of the Study}

The population consists of all eighth female graders in Rafah Governorate schools for the scholastic year $2019-2020$.

\section{Sample of the Study}

The participants of the research consist of 119 female pupils categorized into three groups; the first experimental group consists of 40 pupils; the second experimental group includes 40 pupils and the control group includes 39 pupils. The participants of the research were selected from Kuwait Secondary School for Girls in Rafah Governorate. The participants of the research were randomly selected from Grade eight and equally separated into three groups.

\section{Instrumentation}

\section{Reading Comprehension Test (Pre \& post)}

- The purpose of the Reading Comprehension Test

The exam was an important tool in the research that attempted to check the impact of employing KWL and SQ3R strategies on improving reading comprehension skills.

\section{- Validity of the Test}

The validity of the reading comprehension exam was checked through to the trial implementation. The next procedures were followed:

\section{Referee Validity}

The reading comprehension exam was emphasized via a group of instructors in Gaza colleges and universities, educational specialists and experienced teachers. They are asked to check if the items of the test are suitable. According to their suggestions, some changes were done.

\section{The Pilot Study}

The exam was implemented on a random sample of (40) pupils. The findings were listed and statistically examined to check their validity. The questions of the exam were adapted according to the statistical outcomes.

\section{Internal Consistency Validity}

The researcher employed Pearson correlation coefficient to measure the internal consistency of the reading achievement exam items. To compute that validity, Pearson Correlation measured the correlation of: the questions with their domain, the questions with the total exam and the domains with the exam as a whole.

\section{- Reliability of the Exam}

The reliability of the test was calculated via the Spilt- half technique and KR20.

\section{Split-half Method}

The findings illustrate that the Spilt-half coefficient was (0.842) and KR20 was (0.926) and that refers that the reliability of the exam is strong and high.

\section{Findings, Results, and Data Analysis}

1. Answer of the First Question: Are there statistically significant differences at $(\alpha \leq 0.05)$ in the total mean scores in the reading comprehension skills posttest between the first experimental group that learns by KWL strategy and control group that learns by the traditional method?

For answering the first question, the following null hypothesis was tested : 
There are no statistically significant differences at $(\alpha \leq 0.05)$ in the total mean scores in the reading comprehension skills posttest between the first experimental group that learns by KWL strategy and control group that learns by the traditional method.

To investigate this hypothesis, standard deviations and means of the pupils' finding on the post-test were calculated. The results that obtained from the posttest here were the results of pupils in experimental group 1 and the control group. Independent Samples T-test is employed to compute the significance of the differences. Table (1) illustrates those findings:

Table (1): T-test Independent Sample Results of Differences between the Experimental Group

One and the Control Group in the Post Reading Comprehension Skills Exam

\begin{tabular}{|c|c|c|c|c|c|c|c|}
\hline scope & group & $\mathbf{N}$ & Mean & Std. Deviation & $\mathbf{t}$ & $\begin{array}{c}\text { Sig. } \\
\text { value }\end{array}$ & sig. level \\
\hline \multirow{2}{*}{ Skimming } & Control & 39 & 5.590 & 2.035 & \multirow{2}{*}{6.847} & \multirow{2}{*}{0.000} & \multirow{2}{*}{$\begin{array}{c}\text { sig. at } \\
0.01\end{array}$} \\
\hline & Experimental1 & 40 & 8.450 & 1.663 & & & \\
\hline \multirow{2}{*}{ Scanning } & Control & 39 & 7.103 & 2.703 & \multirow{2}{*}{6.043} & \multirow{2}{*}{0.000} & \multirow{2}{*}{$\begin{array}{c}\text { sig. at } \\
0.01\end{array}$} \\
\hline & Experimental1 & 40 & 10.150 & 1.673 & & & \\
\hline \multirow{2}{*}{$\begin{array}{c}\text { Synonyms and } \\
\text { Antonyms } \\
\end{array}$} & Control & 39 & 3.923 & 1.965 & \multirow{2}{*}{6.954} & \multirow{2}{*}{0.000} & \multirow{2}{*}{$\begin{array}{c}\text { sig. at } \\
0.01\end{array}$} \\
\hline & Experimental1 & 40 & 6.500 & 1.261 & & & \\
\hline \multirow{2}{*}{ Inferences } & Control & 39 & 4.026 & 1.614 & \multirow{2}{*}{9.243} & \multirow{2}{*}{0.000} & \multirow{2}{*}{$\begin{array}{c}\text { sig. at } \\
0.01\end{array}$} \\
\hline & Experimental1 & 40 & 7.325 & 1.559 & & & \\
\hline \multirow{2}{*}{ Taking notes } & Control & 39 & 4.051 & 2.025 & \multirow{2}{*}{7.199} & \multirow{2}{*}{0.000} & \multirow{2}{*}{$\begin{array}{c}\text { sig. at } \\
0.01\end{array}$} \\
\hline & Experimental1 & 40 & 7.475 & 2.195 & & & \\
\hline \multirow{2}{*}{ Total } & Control & 39 & 24.692 & 7.473 & \multirow{2}{*}{10.627} & \multirow{2}{*}{0.000} & \multirow{2}{*}{$\begin{array}{c}\text { sig. at } \\
0.01\end{array}$} \\
\hline & Experimental1 & 40 & 39.900 & 5.042 & & & \\
\hline
\end{tabular}

As illustrated in table (1) the T. computed value was bigger than T. table value in the exam, that refers there are significant differences at $(\alpha \leq 0.01)$ in the overall rate score of the post-test between the experimental group 1 and the control group in favor of the experimental group1.

The mean of the post-test in the experimental group1 is (39.900), while the mean of the control group is (24.692). The outcome refers that the employing of KWL strategy is more efficient than the normal way in improving the pupils' reading comprehension skills.

2. Answer of the Second Question: Are there statistically significant differences at $(\alpha \leq 0.05)$ in the total mean scores in the reading comprehension skills posttest between the second experimental group that learns by SQ3R strategy and the control group that learns by the traditional method?

For answering the second question, the following null hypothesis was tested: There are no statistically significant differences at $(\alpha \leq 0.05)$ in the total mean scores in the reading comprehension skills posttest between the second experimental group that learns by SQ3R strategy and the control group that learns by the traditional method.

To investigate this hypothesis, standard deviations and means of the pupils' finding on the post-test were calculated. The results that obtained from the posttest here were the results of pupils in experimental group 2 and the control group. Independent Samples T-test is employed to compute the significance of the differences. Table (2) illustrates those findings:

Table (2): T-test Independent Sample Findings of Differences between the Experimental

Group 2 and the Control Group in the Post Reading Comprehension Skills Exam

\begin{tabular}{|l|c|c|c|c|c|c|c|} 
scope & group & N & Mean & Std. Deviation & $\mathbf{t}$ & Sig. & sig. \\
\hline
\end{tabular}




\begin{tabular}{|c|c|c|c|c|c|c|c|}
\hline & & & & & & value & level \\
\hline \multirow{2}{*}{ Skimming } & Control & 39 & 5.590 & 2.035 & \multirow{2}{*}{3.366} & \multirow{2}{*}{0.001} & \multirow{2}{*}{$\begin{array}{c}\text { sig. at } \\
0.01\end{array}$} \\
\hline & Experimental2 & 40 & 7.175 & 2.147 & & & \\
\hline \multirow{2}{*}{ Scanning } & Control & 39 & 7.103 & 2.703 & \multirow{2}{*}{3.182} & \multirow{2}{*}{0.002} & \multirow{2}{*}{$\begin{array}{c}\text { sig. at } \\
0.01\end{array}$} \\
\hline & Experimental2 & 40 & 8.900 & 2.307 & & & \\
\hline \multirow{2}{*}{$\begin{array}{c}\text { Synonyms and } \\
\text { Antonyms }\end{array}$} & Control & 39 & 3.923 & 1.965 & \multirow{2}{*}{3.581} & \multirow{2}{*}{0.001} & \multirow{2}{*}{$\begin{array}{c}\text { sig. at } \\
0.01\end{array}$} \\
\hline & Experimental2 & 40 & 5.500 & 1.948 & & & \\
\hline \multirow{2}{*}{ Inferences } & Control & 39 & 4.026 & 1.614 & \multirow{2}{*}{3.282} & \multirow{2}{*}{0.002} & \multirow{2}{*}{$\begin{array}{c}\text { sig. at } \\
0.01\end{array}$} \\
\hline & Experimental2 & 40 & 5.775 & 2.922 & & & \\
\hline \multirow{2}{*}{ Taking notes } & Control & 39 & 4.051 & 2.025 & \multirow{2}{*}{3.100} & \multirow{2}{*}{0.003} & \multirow{2}{*}{$\begin{array}{c}\text { sig. at } \\
0.01\end{array}$} \\
\hline & Experimental2 & 40 & 5.600 & 2.394 & & & \\
\hline \multirow{2}{*}{ Total } & Control & 39 & 24.692 & 7.473 & \multirow{2}{*}{4.622} & \multirow{2}{*}{0.000} & \multirow{2}{*}{$\begin{array}{c}\text { sig. at } \\
0.01\end{array}$} \\
\hline & Experimental2 & 40 & 32.950 & 8.370 & & & \\
\hline
\end{tabular}

As illustrated in table (2) the T. computed value is bigger than T. table value in the test, that indicates there are significant differences at $(\alpha \leq 0.01)$ in the overall rate score of the post-test between the experimental group 2 and the control group in favor of the experimental group2.

The mean of the post-test in the experimental group 2 is (32.950), while the mean of the control group is (24.692). The finding refers that the employing of SQ3R strategy is more efficient than the normal way in improving the students' reading comprehension skills.

3. Answer of the Third Question: Are there statistically significant differences at $(\alpha \leq 0.05)$ in the total mean scores in the reading comprehension skills posttest between the first experimental group that learns by KWL strategy and second experimental group that learns by SQ3R strategy?

For answering the third question, the following null hypothesis was tested:

There are no statistically significant differences at $(\alpha \leq 0.05)$ in the total mean scores in the reading comprehension skills posttest between the first experimental group that learns by KWL strategy and second experimental group that learns by SQ3R strategy.

To investigate this hypothesis, standard deviations and means of the pupils' finding on the post-test were calculated. The results that obtained from the posttest here were the results of pupils in experimental group 1 and the experimental group 2. Independent Samples T-test is employed to compute the significance of the differences. Table (3) illustrates these findings.

Table (3): T-test Independent Sample Results of Differences between the Mean Scores of the Experimental Groups 1 and 2 in the Post Reading Skills Exam

\begin{tabular}{|c|c|c|c|c|c|c|c|}
\hline & group & $\mathbf{N}$ & Mean & Std. Deviation & $\mathbf{t}$ & Sig. alue & sig. level \\
\hline \multirow{2}{*}{ Skimming } & Experimental 1 & 40 & 8.450 & 1.663 & 2.969 & 0.004 & sig. at \\
\cline { 2 - 9 } & Experimental 2 & 40 & 7.175 & 2.147 & & & 0.01 \\
\hline \multirow{2}{*}{ Scanning } & Experimental 1 & 40 & 10.150 & 1.673 & 2.774 & 0.007 & $\begin{array}{c}\text { sig. at } \\
\end{array}$ \\
\cline { 2 - 9 } & Experimental 2 & 40 & 8.900 & 2.307 & & & 0.01 \\
\hline Synonyms and & Experimental 1 & 40 & 6.500 & 1.261 & 2.726 & 0.008 & sig. at \\
\hline
\end{tabular}




\begin{tabular}{|c|c|c|c|c|c|c|c|}
\hline Antonyms & Experimental 2 & 40 & 5.500 & 1.948 & & & 0.01 \\
\hline \multirow{2}{*}{ Inferences } & Experimental 1 & 40 & 7.325 & 1.559 & \multirow[t]{2}{*}{2.960} & \multirow[t]{2}{*}{0.004} & \multirow{2}{*}{$\begin{array}{c}\text { sig. at } \\
0.01\end{array}$} \\
\hline & Experimental 2 & 40 & 5.775 & 2.922 & & & \\
\hline \multirow{2}{*}{ Taking notes } & Experimental 1 & 40 & 7.475 & 2.195 & \multirow[t]{2}{*}{3.650} & \multirow[t]{2}{*}{0.000} & \multirow{2}{*}{$\begin{array}{c}\text { sig. at } \\
0.01\end{array}$} \\
\hline & Experimental 2 & 40 & 5.600 & 2.394 & & & \\
\hline \multirow{2}{*}{ Total } & Experimental 1 & 40 & 39.900 & 5.042 & \multirow[t]{2}{*}{4.499} & \multirow[t]{2}{*}{0.000} & \multirow{2}{*}{$\begin{array}{l}\text { sig. at } \\
0.01\end{array}$} \\
\hline & Experimental 2 & 40 & 32.950 & 8.370 & & & \\
\hline
\end{tabular}

"t $t$ " table value at (78) d f. at (0.05) sig. level equal 2.00 " $t$ " table value at (78) $\mathrm{d}$ f. at (0.01) sig. level equal 2.66

As illustrated in table (3) the T. computed value is bigger than T. table value in the exam, that refers there are significant differences at $(\alpha \leq 0.01)$ in the overall rate score of the post-test between the experimental group1 and experimental group2 in favor of the experimental group 1.

The mean of the post-test in the experimental group1 is (39.900), while the mean of the experimental group 2 is (32.950). The finding refers that employing KWL strategy is more efficient than the SQ3R strategy in improving the learners' reading comprehension skills.

\section{Finding and Interpretation of the First Hypothesis:}

The researcher found the mean of the post-test in the experimental group1 is (39.900), while the mean of the control group is (24.692). The finding refers that the employing of KWL strategy is more efficient than the normal way in improving the pupils' reading comprehension skills.

This big impact perhaps because of the exercises and clear steps that employed via the KWL strategy that attempted to improve reading comprehension skills among $8^{\text {th }}$ graders. Also, the finding that implies to the good impact of KWL strategy can be attributed to fact that this strategy provides a chance for learners to share and involve in the different texts via asking them what they actually want to find out. Furthermore, this strategy encourages the thoughts that give learners the chance to be the center of the teaching-learning process, instead of instructors. In addition, it qualifies students to determine and lead their own learning. Moreover, it activates and arouses learners' motivation to study and qualifies them to learn different texts even if they are hard. Finally, it assists learners to keep information for long time and it stimulates their previous information.

\section{Finding and Interpretation of the Second Hypothesis:}

The researcher found the mean of the post-test in the experimental group2 is (32.950), while the mean of the control group is (24.692). The finding refers that the employing of SQ3R strategy is more efficient than the normal way in improving the learner' reading comprehension skills.

This big impact perhaps because of the exercises and procedures that employed in the SQ3R strategy that attempted to improve reading comprehension skills among $8^{\text {th }}$ graders. Also, the findings that obtained maybe because of the effectiveness of the SQ3R strategy as it assists learners to put their personal objectives for getting data from reading passages. As a result, through employing this strategy with its five steps, learners could revise all the needed data on the passage only in short time if they want to make revision for exams. They can comprehend reading passages fast via employing this method. Learners can divide long passages into enjoyable note to read. Furthermore, SQ3R strategy stimulates learners to employ their thinking and abstract reasoning capacities while improving inquiries. 


\section{Finding and Interpretation of the Third Hypothesis:}

The researcher found the mean of the post-test in the experimental group1 is (39.900), while the mean of the experimental group 2 is (32.950). The finding refers that employing KWL strategy is more efficient than the SQ3R strategy in improving the learners' reading comprehension skills. The researcher thinks that is because KWL strategy includes three simple steps while in the SQ3R strategy there are five steps, and it takes more time in completing activities.

This big impact perhaps because of the exercises and clear steps that employed via the KWL strategy that attempted to improve reading comprehension skills among $8^{\text {th }}$ graders. Also, the finding that implies to the good impact of KWL strategy can be attributed to fact that this strategy provides a chance for learners to share and involve in the different texts via asking them what they actually want to find out. Additionally, this strategy encourages the thoughts that give learners the chance to be the center of the teaching-learning process, instead of instructors. Furthermore, it qualifies students to determine and lead their own learning. Moreover, it activates and arouses learners' motivation to study and qualifies them to learn different texts even if they are hard. Finally, it assists learners to keep information for long time and it stimulates their previous information.

\section{Conclusion}

Relied on the results that elicited from the current research, these conclusions can be introduced:

1. After the study has been conducted, it can be concluded that KWL and SQ3R strategies are good strategies for reading comprehension because they can make the pupils participate well in the class. KWL and SQ3R strategies consist of some organized steps and divide the students into groups. They can help teachers to arrange the learners easily.

2. The process of the implementation of the KWL and SQ3R strategies during the treatment shows that the steps in these two strategies could assist the pupils to understand the reading passage fast.

3. Pupils are obviously involved in learning with the KWL and SQ3R strategies than the normal method because KWL and SQ3R strategies were more interesting.

4. The KWL and SQ3R strategies activate information and imagination about the passage even before students start reading.

5. The KWL and SQ3R strategies activate and arouses learners' motivation to imagine and gives them the chance to study materials even if they are hard.

\section{Recommendations}

1. Improving teacher's capacities in teaching English via planning training courses to stimulate and activate the use of modern methods and techniques such as KWL and SQ3R Strategies.

2. Minimizing the number of the pupils in classrooms to give instructors the chance to care for individual differences between pupils and application innovative methods of instructing particularly KWL and SQ3R Strategies. The procedures that will be taken about Corona virus will help to achieve this.

3. Providing teachers with new methods for instructing various skills especially reading skills with its lesson plans.

4. Planning training courses to activate the employing of the modern methods such as KWL and SQ3R strategies and to improve instructors' capacities in instructing reading skills.

5. Considering pupils' individual differences and learning styles in KWL and SQ3R tasks and activities. 


\section{References}

Abdal Rahim, A. (2015). The Effectiveness of KWL Strategy on Palestinian Eleventh Graders' Reading Comprehension, Vocabulary and its Retention and Students' Attitudes Towards English. (Unpublished Master Thesis). The Islamic University of Gaza.

Afida, A. (2008). Improving Students' Reading Comprehension Using Reciprocal Questioning Technique: A Classroom Action Research in SMK Diponegoro Salatiga, (Unpublished Master Thesis). Sebelas Maret University.

Al-salhi, N. (2020). The Effects of the Use of the Know-Want-Learn Strategy (KWL) on Fourth Grade Students' Achievement in Science at Primary Stage and Their Attitudes towards it. EURASIA Journal of Mathematics, Science and Technology Education, 16(4), 15-30.

Al-Taie, S. (2010). The Effect of Applying K-W-L Technique on Teaching ESP University of Baghdad. Retrieved on: 28/07/2020. From: http://www.google.ps

Alyousef, S. (2005). Teaching Reading Comprehension to ESL/EFL Learners. The Reading Matrix, $5(2), 143-154$.

Asiri, A. \& Momani, M.(2017). The Effectiveness of Using SQ3R to Teach Reading Skills. Asian Journal of Educational Research. 5, (1).

Asri, A. (2014). Implementing KWL Strategy in Teaching Reading for Non-English Department Students. The 61 TEFLIN International Conference, UNS Solo

Badr El Deen, Z. (2009). The Effectiveness of Assisted Extensive Reading on Developing Reading Comprehension Strategies for Ninth Graders in Gaza governorate. (Unpublished Master Theses). Islamic University of Gaza.

Baier, K. (2011). The Effect of SQ3R on Fifth Grade Students' Comprehension Levels. (Unpublished Master Thesis). Ohio: Bowling Green State University.

Bakhtiar, A. (2018). Improving Students' Reading Comprehension by Using SQ3R Method. Journal of English Language Teaching. (2),(2), 1-10.

Behjat, F. (2011). Reading Through Interaction: From Individualistic Reading Comprehension to Collaborating, Theory and Practice in Language Studies Journal, 1(3), 239-244.

College of the Canyons (2012). Skills 4 Success: Supplemental Learning Workbook. Retrieved on: 17/08/2020. From: http://www.canyons.edu.

Conner, J. (2006). Advanced study of the Teaching of Secondary school Reading Instructional Reading Strategy: KWL (Know, Want to Learn, Learned). Retrieved on: 27/08/2020. From: http://www.indiana.edu/ 1517/KWL.htm

Dieu, T (2016). Trying K-W-L Strategy on Teaching Reading Comprehension to Passive Students in Vietnam. International Journal of Language and Linguistics: 3(6), 481- 492.

El-Kahlout, Y. (2010). The Effectiveness of Using Guided Discovery on Developing Reading Comprehension Skills for the Eleventh Graders in Gaza, Governorates. (Unpublished Master Theses). Al-Azhar University, Gaza.

English for Palestine Teacher's .Book 8. (2013). Macmillan Publishers Limited. www.englishforpalestine.com

Fikri, A. (2015 ). Using SQ3R Method to Improve Reading Comprehension of the Students XI Class of SMA ITMA Jombang. EDUSCOPE, Vol. 1 No. ISSN : 2460 - 4844.

Fleming, G. (2019). Understanding the SQ3R Study Strategy. Thought co. https://www.thoughtco.com/sq3r-reading-comprehension-strategy-1857535

Hedge, T. (2003). Teaching and Learning in the Language Classroom. UK: OUP. 
Ibrahimi, N. (2012). The Use of K-W-L Technique in Teaching Reading Descriptive Text. University of Indonesia.

Lipson,Y. \& Wixon, K. (2003). Assessment and Instruction of Reading and Writing Disability.(3 ${ }^{\text {rd }}$ edition). NY: Longman.

McKenna, M. (2003). Help for Struggling Readers: Strategies for Grades 3-8. New York: The Guilford Press.

Medina, L. (2012). Effects of Strategy Instruction in an EFL Reading Comprehension Course: A Case Study. Teachers Professional Development Journal,14 (1), 1-8.

Miller, C. (2012). How Prior Knowledge Affects Word Identification and Comprehension. Reading and Writing, (25), 131-149.

Mohamad, A. (1999). What do We Test When We Test Reading Comprehension? The Internet TESL Journal, (12), 1-2.

Ogle, M. (1986). K-W-L: A Teaching Model that Develops Active Reading of expository text. Reading Teacher, (39), 564-570.

Paran, A. (2003). Intensive Reading English Teaching Professional, 28,40- 48.Cambridge: Cambridge University Press.

Pribadi, G. (2016). Using SQ3R Reading Strategy to Improve Reading Comprehension of Tenth Graders at SMA Negeri 1 Srengat. (Unpublished Master Thesis). State University of Malang

Rahman, H. (2019). An Evaluation of the Teaching of Reading Skills of English in Bangladesh. (Unpublished Master Thesis). Bangladesh: University of Rajshahi.

Rakhmawati, D. (2015). The Effectiveness of Know -Want to Know-Learned (KWL) Strategy in Reading Comprehension. Journal SMART. 1 (1), 25-31.

Robinson, P. (1941). Effective study. ( $1^{\text {st }}$ ed.) New York: Harper and Row Publishers.

Rusmati , T. (2017). Using KWL Strategy to Improve Students' Reading Comprehension. English Education Study Program Language and Art Education Department Teacher Training and Education Faculty Tanjungpura University Pontianak

Salah, S. (2008). The Relationship between Vocabulary Knowledge and Reading Comprehension of Authentic Arabic Texts. Brigham, Young University.

Sasson, D. (2008). Use K-W-L technique in reading lessons: Strategic thought process For engaging students before they read. Retrieved on: 15/08/2020. From: http://newteachersupport.suite101.com/article.cfm

Simmons, L. et al. (2011). The Effects of an Intensive Shared Book-reading Intervention for Preschool Children at Risk for Vocabulary Delay. Exceptional Children, 77(2), 161-183.

Stahl, D. (2003). The Effects of Three Instructional Methods on the Reading Comprehension and Content Acquisition of Novice Readers. Paper presented at the Meeting of the National Reading Conference, Scottsdale, AZ.

Szabo, S. (2006). A student-driven Evolution of the KWL. American Secondary Education, 34(3), 57-67.

Takase, A. (2009). The Effects of Different Types of Extensive Reading Materials on Reading Amount, Attitude and Motivation. In A. Cirocki (Ed.), Extensive Reading in English Language Teaching. Munich: LINCOM Europa.

Usman, B., Fata,I. \& Pratiwi, R. (2018). Teaching Reading Through Know- Want- Learned (KWL) Strategy: The Effects and Benefits. Englisia Journal. 6, (1), 35-42

Waring, R. (1997). Graded and Extensive Reading-Questions and answers. The Language Teaching Online. Available: http://jaH-publications. Ogr/ttt/files//79/may/Waring. Html.

Willis, J. (2009). A framework for task-based learning. Harlow, Essex: Longman. 
Wood, N. (2000). College Reading. Purposes and strategies. Prentice-Hall, Inc. Upper Saddle River, New Jersey.

Yang, W., Dai, W.,\& Gao, L. (2012). Intensive Reading and Necessity to Integrate Learning Strategies. English Language and Literature. 2(1), 55-63. 